\title{
FLUKTUASI INDEKS SAHAM GLOBAL YANG PERLU DIPERHATIKAN UNTUK TRADING SAHAM SEKTOR FINANCE DI INDONESIA
}

\author{
Nugroho Wisnu Murti ${ }^{*}$, Indriyana Widyastuti ${ }^{2}$, Saptani Rahayu ${ }^{3}$ \\ Sekolah Tinggi Ilmu Ekonomi Adi Unggul Bhirawa Surakarta \\ Email: *nugroho.wm@stie-aub.ac.id
}

\begin{abstract}
ABSTRAK
Penelitian ini dikembangkan tidak hanya memberikan pertimbangan pada investasi saham pada dengan mempertimbangkan fluktuasi indeks saham internasional.Akan tetapi juga melakukan analisis pada Informasi ini penting untuk mempertimbangkan investasi saham yang lebih fokus pada sektor tertentu karena beberapa penelitian terdahulu yang lebih banyak memberikan pertimbangkan alternative investasi dengan melakukan analisis pada indeks harga saham gabungan. Data yang digunakan adalah data time series fluktuasi harga saham mingguan indeks harga saham internasional antara lain Dow Jones 30, Hangseng, Nikkei, dan Strait Times dari tahun 2008 sampai dengan 2018 yang diestimasi untuk memprediksi pergerakan indeks harga saham finance indonesia. Penelitian ini menemukan bahwa beberapa indeks internasional yang diobservasi memiliki hubungan yang kuat dengan fluktuasi indeks saham finance Indonesia. Akan tetapi arah hubungan tersebut berbeda-beda. Akan tetapi informasi yang lebih harus diketahui adalah hampir semua indeks tersebut memilikibeda yang signifikan antara indeks internasional ketika diestimasi dalam model yang memiliki efek terhadap reaksi pada pasar modal di Indonesia. Temuan tersebut memberikan implikasi praktis bahwa ketika investor memperhatikan indeks internasional untuk memprediksi arah reaksi pasar modal Indonesia, indeks - indeks tersebut perlu diperhatikan semuanya secara spesifik. Penelitian ini mengidentifikasi dalam enam perbedaan antara dua indeks internasional terhadap pergerakan indeks finance Indonesia.
\end{abstract}

Kata kunci: Sektor Finance, Trading, Investasi, Saham Global, Indeks

\section{PENDAHULUAN}

Penelitian Capital Market menjadi salah satu penelitian terapan yang sering ditunggu hasilnya untuk menjadi salah satu pertimbangan investasi maupun trading.Fluktuasi harga saham sering dikaitkan dengan berbagai faktor, terlebih lagi aktivitas perdagangan saham saat ini diisukan lebih didominasi trader dibandingkan dengan tujuan investasi.Penelitian fenomenal yang mengakibatkan fluktuasi harga saham tersebut dengan informasi akuntansi adalah Ball \& Brown, (1968) dan kembali menuliskan kembali tentang keterkaitan informasi akuntansi tersebut pada tahun 2019 (Ball \& Brown, 2019). Akan tetapi riset terakhir Ball \& Brown tersebut memberikan penjelasan bahwa relevansi informasi akuntansi terhadap aktivitas capital market memiliki penurunan di beberapa negara maju. Temuan tersebut relevan dengan penjelasannya lain bahwa informasi akuntansi sesungguhnya selalu bersaing dengan informasi dalam mempengaruhi keputusan trading maupun investasi (Scott, 2015, p. 141). Ketika informasi akuntansi terbukti relevan dengan fluktuasi pada level harga saham, return maupun abnormal return maka kondisi tersebut dapat dijelaskan dengan teori Efisien Market Hypothesis (EMH) setengan tua sebagaimana yang dirumuskan oleh (Fama, 1970).

Jika mendasarkan pada hasil riset Ball \& Brown, (2019), maka riset ini menduga pasar saham pada negara berkembang memiliki potensi penurunan relevansi yang lebih besar dibandingkan dengan maju. Artinya, EMH pasar jenis setengah kuat akan semakin sulit dibuktikan pada aktivitas pasar saham di negara berkembang. Argumen tersebut juga didasarkan pada beberapa temuan Random Walk Hypothesis (RWH) yang terbukti di negara berkembang (Al-Khazali, 2008; Ardianti \& Mirza, 2016; Burke et al., 2005; Joel, Abakah, \& Alagidede, 2018; Kumar \& Dhankar, 2017; Mollah \& Mobarek, 2009).Temuan aktivitas pasar modal pada 
negara berkembang yang dapat dijelaskan dengan RWH tersebut sesungguhnya tidak sepenuhnya dapat dijelaskan dengan EMH bentuk lemah.Karena EMH bentuk lemah menjelaskan tentang fluktuasi harga yang memiliki hubungan erat dengan harga historis saham terkait.Sementara RWH menjelaskan bahwa membuka ruangan yang lebih luas untuk menjelaskan faktor yang mempengaruhi pergerakan harga saham, terlebih lagi aktivitas pasar modal merupakan aktivitas trading dan investasi yang melibatkan berbagai negara.Sehingga berbagai macam informasi dan kondisi apapun yang berpotensi mempengaruhi keputusan trading maupun investasi, adalah sangat layak untuk diteliti.

Observasi penelitian ini dilakukan pada aktivitas perdagangan saham di Indonesia. Pertimbangan utama pemilihan lokasi ini adalah perkembangan pasar saham di negara ini relatif pest dibandingkan dengan negara lain, tapi isu karakteristik thin market pada negara ini masih melekat ${ }^{1}$. Sehingga penelitian aktivitas pasar modal pada salah satu negara berkembang ini penting untuk dilakukan dengan harapan dapat replicable untuk penelitian selanjutnya di negara lain. Penelitian ini fokus pada informasi keuangan yang berasal dari aktivitas pasar modal di negara lain yang berpotensi memiliki hubungan erat dengan fluktuasi harga saham di Indonesia. Aktivitas perdagangan perdagangan luar negeri yang diobservasi dalam penelitian ini adalah indeks harga saham beberapa negara antara lain Amerika Serikat, Jepang, China, dan Singapura. Namun demikian penelitian ini menduga bahwa ada kemungkinan bahwa fluktuasi indeks saham internasional ini akan berbeda dalam mempengaruhi indeks sectoral tertentu meskipun secara agregat dapat diwakili dengan composite indeks. Akan tetapi spesifikasi portofolio investasi maupun trading membutuhkan pertimbangan yang lebih spesifik untuk menentukan saham jenis apa yang potensi dan peluang return yang lebih besar. Sehingga penelitian ini fokus hanya pada indeks sektoral finance.

\section{TELAAH LITERATUR}

Fluktuasi indeks harga saham internasional juga berpotensi menjadi bad news maupun goodnews bagi aktivitas perdagangan saham di Indonesia. Pendapat tersebut relevan dengan penjelasan tentang Signaling Theory yang dapat ditunjukan dengan fenomena bahwa Informasi yang dipublikasikan sebagai suatu pengumuman akan memberikan sinyal bagi investor dalam pengambilan keputusan investasi, misalkan pengumuman yang mengandung nilai positif, diharapkan pasar akan bereaksi pada waktu pengumuman tersebut (Jogiyanto, 2003: 392). Pada waktu informasi diumumkan dan semua pelaku pasar sudah menerima informasi tersebut, pelaku pasar terlebih dahulu menginterpretasikan dan menganalisis informasi tersebut sebagai sinyal baik (good news) atau sinyal buruk (bad news) dan akan terjadi perubahan volume perdagangan saham (Jogiyanto, 2003: 392).

\footnotetext{
${ }^{1}$ Informasi yang menunjukakan bahwa pasar modal di Indonesia termasuk yang terbaik dapat ditunjukkan pda link berikut: https://www.vivanews.com/indepth/wawancara/1995-pasar-modalindonesia-salah-satu-terbaik-di-asia?medium=autonext; $\quad$ https://finance.detik.com/bursa-dan-valas/d4362910/data-bei-ihsg-urutan-ke-8-di-dunia
} 
Sebagian besar penelitian terdahulu di Indonesia yang mengestimasi pengaruh saham internasional terhadap saham Indonesia fokus pada Indeks saham Saham gabungan atau beberapa indeks konstituen lain (Artini, Aryati, Lestari, Darmayanti, \& Sudiartha, 2017; Bery \& Worokinasih, 2018; Kowanda, Binastuti, \& Pasaribu, 2014; Widodo, 2017). Observasi terhadap fluktuasi Jakarta Islamic Indeks juga pernah dikaitkan dengan pergerakan indeks saham internasional yang terbukti signifikan (Faridatun, Azib, \& Senjiati, 2017).Akan Tetapi beberapa penelitian tersebut belum secara spesifik meneliti pada saham sektoral di Indonesia.Meskipun IHSG dapat dikatakan dapat mewakili pergerakan harga saham seluruhnya baik pada sektoral maupun konstituante, namun pertimbangan portofolio membutuhkan rekomendasi yang lebih spesifik.Dengan demikian penelitian ini menawarkan pertimbangan trading dan investasi saham pada sektor tertentu (finance) berdasarkan pergerakan saham internasional.

Selain beberapa penelitian daiatas, penelitian terhadap capital market terkait dengan faktor makro ekonomi sampai saat ini banyak menghasilkan produk pertimbangan dalam menentukan pertimbangan portofolio investasi jangka panjang. Penelitian tersebut antara lain yang meneliti Nilai tukar, Suku bunga, Laju inflasi dan Pertumbuhan GDP untuk menganalisis keputusan investasi jangka panjang (Kewal, 2012; Raharjo, 2010; Thobarry, 2009). Rumusan variabel fluktuasi makro ekonomi sebagai faktor yang mempengaruhi pergerakan harga saham juga dilakukan peneliti lain di luar negeri antara lain (Alshogeathri, 2011; Bali, Brown, \& Caglayan, 2014; Baltacı \& Ayaydın, 2014; Zhu, 2012).

Penelitian ini menduga bahwa indeks sektoral secara spesifik juga memiliki hubungan yang erat dengan aktivitas perdagangan internasional.Dugaan tersebut berdasarkan temuan empiris diatas yang menjelaskan tentang hubungan yang erat antara pergerakan harga saham internasional dengan IHSG.Dengan demikian Hipotesis 1 penelitian ini adalah Indeks dowjones, Strait Times, Nikkei dan Hangseng berpengaruh signifikan secara parsial terhadap Indeks saham Sektor Finance Indonesia.Namun demikian secara spesifik penelitian terdahulu yang disampaikan diatas diatas belum melihat apakah terdapat perbedaan yang signifikan antara indeks saham internasional tersebut dalam mempengaruhi harga saham di Indonesia.Dengan demikian additional analisis dilakukan untuk melihat secara spesifik perbedaan tersebut sebagai bahan pertimbangan apakah diperlukan perhatian yang seimbang antara indeks global tersebut. Penelitian ini menduga terdapat perbedaan antar indeks global tersebut dalam mempengaruhi Indeks finance Indonesia dengan pertimbangan bahwa Indeks global tersebut dirumuskan dari negara yang berbeda. Dengan demikian Hipotesis kedua yang dirumuskan adalah: terdapat beda signifikan masing-masing indeks global terhadap indeks finance Indonesia.

\section{METODE PENELITIAN}

Objek penelitian ini adalah fluktuasi harga saham emiten di sektor finance dan beberapa indeks saham internasional antara lain Dow Jones 30, Hangseng, Nikkei, dan Strait Times. Pemilihan obyek ini mempertimbangkan bahwa jumlah emiten terbesar pada sektor finance diantara sektor lain dan terdapat kecenderungan bahwa emiten pada sektor ini memiliki aktivitas transaksi yang lebih tinggi dibandingkan dengan sektor lain. Populasi penelitian ini adalah data historis fluktuasi harga saham yang tercatat di sektor finance. Pemilihan populasi dengan durasi waktu 10 tahun observasi tersebut telah mempertimbangkan durasi umum waktu minimal untuk melakukan forecasting yaitu lima tahun. Indeks harga saham sektor finance merupakan variabel dependen dalam penelitian ini adalah fluktuasi yang diobservasi secara mingguan. Variabel 
independen yaitu fluktuasi harga indeks saham internasional yang terdiri dari Dow Jones 30, Hangseng, Nikkei, dan Strait Times yang diukur pada harga rata - rata mingguan. Analisis data yang perlu dilakukan untuk mencapai tujuan penelitian adalah robustness multiple regression.Dengan demikian scenario uji heteroskedastisitas dan autokorelasi pada analisis tersebut tidak diperlukan.Akan tetapi uji multikolinearitas diperlukan dalam pengujian ini.Tahap selanjutnya adalah analisis linear combination sebagai additional analisis yang mengetahui apakah terdapat perbedaan signifikan antara variabel independen dalam mempengaruhi variabel dependen. Seluruh analisis data dilakukan dengan menggunakan alat bantu analisis statistic Stata.

\section{HASIL DAN PEMBAHASAN}

Informasi pertama yang dapat disampaikan dalam hasil penelitian ini adalah terkait dengan profil data penelitian yang dapat ditunjukkan pada Tabel 1.Data fluktuasi harga indeks saham mingguan yang dianalisis dalam penelitian ini diperoleh dari www.investing.com. Analisis data dilakukan terhadap harga penutupan rata-rata per minggu pada setiap indeks saham dari 1 Januari 2008 sampai dengan akhir bulan juni 2019. Data historis terlengkap pada durasi data time series tersebut adalah indes finance Indonesia dan Index Dow Jones (595 dan 600 observasi). Sementara itu terdapat beberapa missing value dan data tanggal yang tidak sesuai dengan tanggal aktivitas pada pasar saham pada indeks finance di Indonesia. Penelitian ini menghilangkan missing value tersebut.

Tabel 1. Profile Data

\begin{tabular}{lcrrrr}
\hline \multicolumn{1}{c}{ Variabel } & $\begin{array}{c}\text { Jumlah } \\
\text { Observasi }\end{array}$ & Mean & Std. Dev. & Min & Max \\
\hline Index Finance Indonesia & 595 & 627,82 & 294,15 & 134 & $1.310,38$ \\
Indonesia composite Index & 595 & $4.300,22$ & $1.389,86$ & $1.146,28$ & $6.660,62$ \\
Dow Jones Index & 600 & $15.903,28$ & $5.174,69$ & $6.626,94$ & $26.922,12$ \\
Straits Times Index & 527 & $3.083,86$ & 248,11 & $2.273,18$ & $3.577,21$ \\
Han Seng Index & 527 & $23.431,61$ & $3.194,93$ & $17.592,41$ & $33.154,12$ \\
Nikkei Index & 321 & $18.542,30$ & $2.865,23$ & $12.686,52$ & $24.120,04$ \\
\hline
\end{tabular}

Sumber: analisis statistik deskriptif berdasarkan data yang diunduh dari www.investing.com

Informasi penting lain berdasar Tabel 1 diatas bahwa rata-rata composite index Indonesia selama periode observasi sesungguhnya bukan merupakan yang terendah, akan tetapi Strait Times Index Singapura. terendah dibandingkan dengan Indeks international composite yang lain. Sesungguhnya perbandingan tersebut tidak dapat dilakukan karena beberapa indeks internasional tersebut adalah composite indeks yang tidak terdiri dari satu sektor saja.Jika membandingkan antara kedua negara sesama Asia Tenggara tersebut, Singapura memiliki standar deviasi yang lebih kecil dibanding Indonesia.Artinya.Indonesia memiliki variasi harga saham yang lebih kreatif dibandingkan dengan Singapura.Hal tersebut dapat ditunjukkan dengan nilai minimal dan maksimal indeks yang lebih berdekatan pada indeks saham singapura dibanding Indonesia.Variasi yang lebih besar ini juga dapat dikatakan sebagai salah satu indikasi karakteristik pasar saham Indonesia yang mungkin sebagai emerging capital market dan memiliki karakteristik perdagangan yang tipis (thin market). Jika melihat standar deviasi pada indeks finance, maka aktivitas perdagangan saham pada sektor ini memiliki indikasi lebih 
aktif dibandingkan dengan keseluruhan indeks sectoral lain di Indonesia dengan melihat standar deviasi indeks finance yang lebih kecil dibanding composite indeks Indonesia. Fluktuasi indeks harga saham pada negara tersebut selama periode observasi dapat ditunjukkan pada Gambar 1.

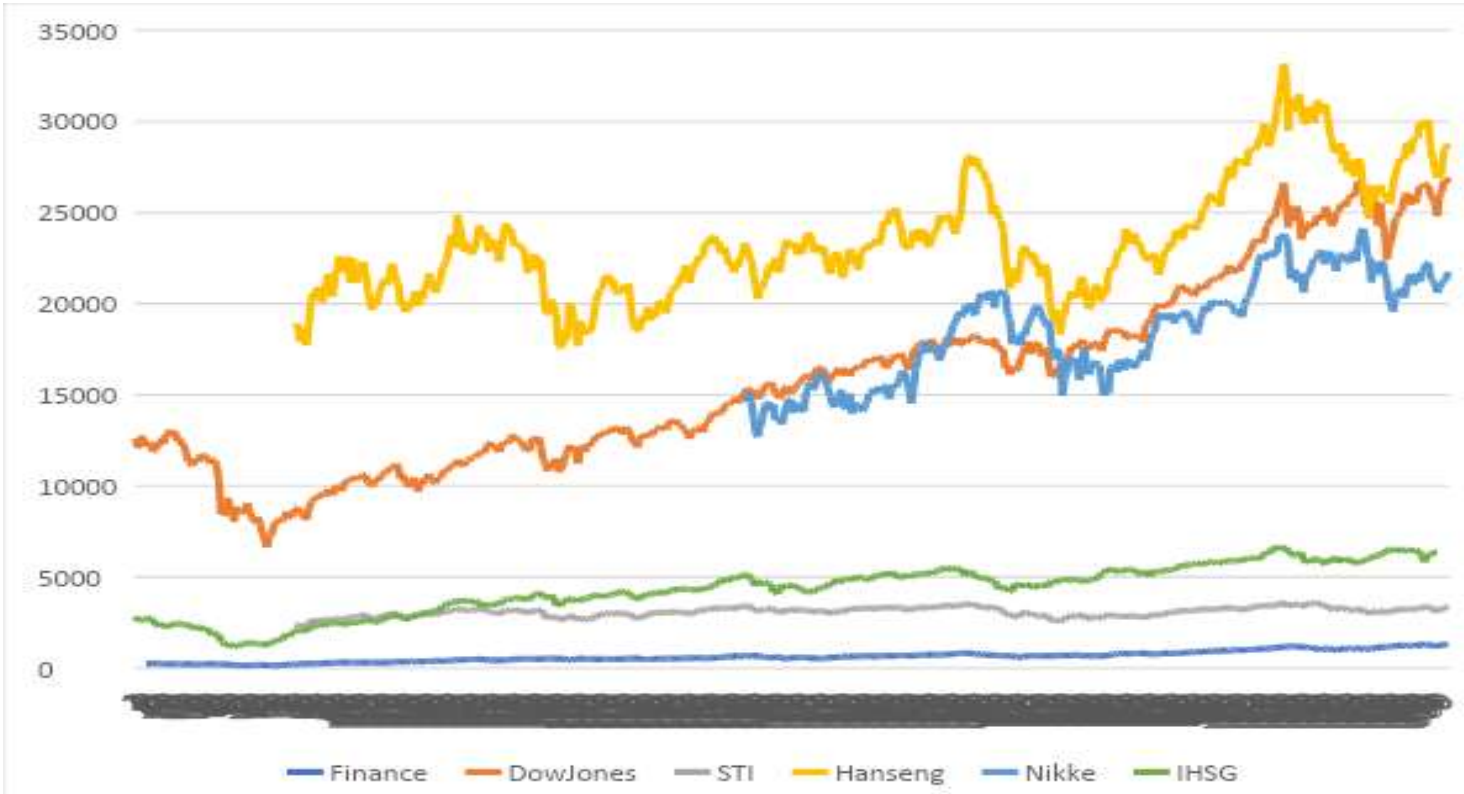

Gambar 1 Perbandingan fluktuasi indeks saham Finance, Dow Jones, STI, Hang Seng, Nikkie dan Composite Index Indonesia (IHSG)

Tahap kedua hasil penelitian ini adalah menguji asosiasi antara indeks saham internasional tersebut dengan fluktuasi saham indeks finance di Indonesia. Alat analisis yang digunakan dalam penelitian ini adalah robustness multiple linier regression yang dilanjutkan dengan analisis linier combination untuk melihat apakah terdapat perbedaan signifikan antara indeks internasional dalam mempengaruhi fluktuasi indeks finance Indonesia. Ringkasan hasil analisis tersebut ditunjukkan pada Tabel 2. Sebelum interpretasi hasil tersebut perlu disampaikan terlebih dahulu bahwa uji multikolinearitas yang atas model persamaan regresi penelitian ini menunjukkan bahwa setiap variabel independen tidak memiliki hubungan yang erat dengan variabel independen lainnya. Hasil menunjukkan bahwa indeks internasional yang dirumuskan dalam model penelitian ini seluruhnya memiliki pengaruh yang signifikan ( $p$-value $<0,01)$ terhadap fluktuasi indeks saham finance Indonesia. Hubungan negatif ditemukan pada Strait Times dan Nikkie Indeks terhadap indeks saham finance. Sementara itu, Dow Jones indeks Amerika dan Hangseng Indeks memiliki hubungan positif terhadap fluktuasi indeks finance Indonesia. Hubungan setiap indeks saham internasional terhadap indeks finance tersebut layak untuk diperhatikan, khususnya sebagai pertimbangan keputusan trading jangka pendek (mingguan) saham yang termasuk dalam sektor keuangan baik bank maupun non perbankan di Indonesia.

Implikasi atas hasil temuan tersebut adalah pertimbangan keputusan trading dengan time limit atau masa holding maksimal selama 1 minggu dengan mendasarkan pada penggunaan data mingguan pada penelitian ini. Keputusan investasi yang dapat dipertimbangkan adalah melakukan keputusan beli terhadap saham yang termasuk dalam sektor keuangan ketika Indeks Dow Jones dan Hangseng Indeks mengalami trend kenaikan.Ketika memperhatikan fluktuasi 
Strait Times Indeks dan Nikkie, keputusan beli saham pada sektor keuangan tersebut dapat dilakukan saat kedua indeks internasional tersebut mengalami penurunan harga.

Tabel 2. Ringkasan hasil uji statistic inference

\begin{tabular}{|c|c|c|c|c|}
\hline Variabel & Coefisien & $\begin{array}{l}\text { Standar } \\
\text { Error }\end{array}$ & $\mathrm{t}$ & $P>t$ \\
\hline Dow Jones Index & 0,0542079 & 0,0023435 & 23,13 & 0,000 \\
\hline Straits Times Index & $-0,0534584$ & 0,0271507 & $-1,97$ & 0,050 \\
\hline Han Seng Index & 0,0121306 & 0,0032944 & 3,68 & 0,000 \\
\hline Nikkei Index & $-0,0070339$ & 0,0022144 & $-3,18$ & 0,002 \\
\hline Konstanta & $-240,1057$ & 54,68275 & $-4,39$ & 0,000 \\
\hline
\end{tabular}

Sumber: Output hasil analisis regresi

Tahap berikutnya adalah mengetahui apakah ada beda signifikan antara indeks internasional tersebut pada model yang diestimasi memiliki efek terhadap pergerakan saham di Indonesia. Informasi tersebut penting untuk mempertimbangan, indeks internasional apa yang mendapat prioritas untuk dapat diperhatikan sebagai pertimbangan investasi. Analisis tersebut dilakukan dengan linear combination yang ringkasannya ditunjukkan pada Tabel 3.Analisis dilakukan dengan membandingkan antara indeks saham Internasional sebagaimana yang disampaikan pada Tabel 3.Hampir semua perbandingan menunjukkan hasil yang signifikan pada P-Value $<0.01$ kecuali membandingkan strait timeindex dengan indeks yang lain (selain Dow jones).Temuan ini memberikan implikasi praktis khususnya untuk memperhatikan Strait time indeks.

Tabel 3.Linier Combination Analysis

\begin{tabular}{lcccc}
\hline \multicolumn{1}{c}{ Variabel } & Coefisien & $\begin{array}{c}\text { Standar } \\
\text { Error }\end{array}$ & $\mathrm{t}$ & $\mathrm{P}>\mathrm{t}$ \\
\hline Dow Jones Index - Straits Times Index & 0,107666 & 0,0263002 & 4,09 & 0,000 \\
Dow Jones Index - Hang Seng Index & 0,061242 & 0,0037925 & 16,15 & 0,000 \\
Dow Jones Index - Nikkei Index & 0,042077 & 0,0050836 & 8,28 & 0,000 \\
Straits Times Index - Hang Seng Index & $-0,06559$ & 0,0299673 & $-2,19$ & 0,029 \\
Straits Times Index - Nikkei Index & $-0,04642$ & 0,0265972 & $-1,75$ & 0,082 \\
Han Seng Index - Nikkei Index & 0,019165 & 0,0045368 & 4,22 & 0,000 \\
\hline
\end{tabular}

Sumber: Output hasil analisis linier combination

Potensi untuk tidak terlalu memperhatikan Strait Time indeks ketika memperhatikan Nikkei dapat dilakukan oleh calon investor.Akan tetapi, ketika memperhatikan Hangseng, indeks saham strait time, masih potensial untuk diperhatikan.Perbedaan paling kuat adalah pada Dow Jones Indeks. Temuan tersebut menegaskan bahwa meskipun sentiment investasi pada pasar modal china dengan amerika memiliki arah yang sama terhadap investasi di Indonesia, namun kedua indeks tersebut memiliki tingkat pengaruh yang berbeda signifikan. Dow Jones berpotensi lebih besar dibandingkan dengan Hangseng

\section{KESIMPULAN}

Penelitian ini tidak melakukan observasi pada setiap emiten sektor finance di Indonesia. Akan tetapi, secara statistic indeks sectoral ini berpotensi memiliki aktivitas yang tinggi dibandingkan dibandingkan dengan sektor lain berdasarkan pada perundingan standar deviasi 
antara IHSG dengan Sektor Finance. Potensi tersebut memberikan sinyal bahwa karakteristik thin market pada pasar modal Indonesia mungkin bersumber pada saham sektor lain yang identic dengan istilah saham "gorengan", tetapi bukan pada saham pada sektor finance. Temuan lain penting lain yang perlu disampaikan dalam penelitian ini bahwa trading saham dengan durasi minggu pada saham sektor finance di Indonesia perlu memperhatikan fluktuasi indeks saham internasional secara parsial. Hasil penelitian ini dapat merumuskan rekomendasi bahwa indeks dow jones dan hangseng perlu diperhatikan secara terpisah meskipun memiliki arah hubungan yang sama terhadap indeks finance Indonesia. Demikian juga dengan Indeks Nikkei dan Strait Times.

\section{DAFTAR PUSTAKA}

Al-Khazali, O. (2008). The impact of thin trading on day-of-the-week effect Evidence from the United Arab Emirates.Review of Accounting and Finance, 7(3), 270-284. https://doi.org/10.1108/14757700810898258

Alshogeathri, M. A. M. (2011). Macroeconomic Determinants of The Stock Market Movements: Empirical Evidence From The Saudi Stock Market. Dissertation, Doctor of Philosophy, Departement of Economics Collage of Art and Sciences, 1-127.

Ardianti, Y., \& Mirza, A. R. (2016). A testing od Efficient Market Hypothesis in Indoensia Stock Market. In 3rd Global Conference Business and Social Science (Vol. 219, pp. 99103). Kuala Lumpur, Malaysia: Procedia Social and Behavioral Sciences. https://doi.org/10.1016/j.sbspro.2016.04.048

Artini, L. G. S., Aryati, N. T., Lestari, P. V., Darmayanti, N. P. A., \& Sudiartha, G. M. (2017). Analisis Fundamental Makro Dan Integrasi Pasar Saham Dunia Dengan Bursa Efek Indonesia.Jurnal Manajemen, Strategi Bisnis Dan Kewirausahaan, 11(2), 128-135.

Bali, T. G., Brown, S. J., \& Caglayan, M. O. (2014). Macroeconomic risk and hedge fund returns. Journal of Financial Economics, 114(1), 1-19. https://doi.org/10.1016/j.jfineco.2014.06.008

Ball, R., \& Brown, P. (1968).Ball_Brown_JAR_1968.pdf.Journal of Accounting Reserach, 159-178.

Ball, R., \& Brown, P. (2019). Ball and Brown ( 1968 ) after fifty years. Pacific-Basin Finance Journal, 53(December 2018), 410-431. https://doi.org/10.1016/j.pacfin.2018.12.008

Baltacı, N., \& Ayaydın, H. (2014). Firm, Country and Macroeconomic Determinants of Capital Structure: Evidence from Turkish Banking Sector. EMAJ: Emerging Markets Journal, 3(3), 47-58. https://doi.org/10.5195/emaj.2014.46 
Bery, D., \& Worokinasih, S. (2018). Pengaruh Indeks Harga Saham Global Terhadap Indeks Harga Saham Gabungan (IHSG). Jurnal Administrasi Bisnis, 64(1).

Burke, J., Fraser, P., Islam, A., Macgregor, A., Powell, J., Stent, A., ... Zealand, N. (2005). A Variance-Ratio Test of the Random Walk Hypothesis for the New Zealand Share Market: Pasific Accounting Review, 17(2), 53-71.

Fama, E. (1970). Efficient Capital Market: A Review of Theory and Empirical Work. The Journal of Finance, 25(2), 383-417. https://doi.org/10.2307/2325486

Faridatun, A., Azib, \& Senjiati, I. H. (2017).di Jakarta Islamic Index ( JII ). In Pengaruh Indeks Harga Saham Internasional Terhadap Harga Saham di Jakarta Islamic Index (JII) (pp. 536-543).

Joel, E., Abakah, A., \& Alagidede, P. (2018). Non-linear approach to Random Walk Test in selected African countries. International Journal of Manjerial Finance, 14(3), 362-376. https://doi.org/10.1108/IJMF-10-2017-0235

Jogiyanto. (2012). Teori Portofolio dan Analisis Investasi (3rd ed.). Yogyakarta, Indonesia: BPFE Yogyakarta.

Kewal, S. S. (2012). Pengaruh Inflasi, Suku Bunga, Kurs, dan Pertumbuhan PDB Terhadap Indeks Harga Saham Gabungan. Jurnal Economia, 8(1), 53-64.

Kowanda, D., Binastuti, S., \& Pasaribu, R. B. F. (2014).Pengaruh Bursa Saham Global, Asean, Dan Harga Komoditas Terhadap Indeks Harga Saham Gabungan, Dan Nilai Tukar EUR/USD.Jurnal Akuntansi Dan Manajemen, 25(2), 79-88.

Kumar, R., \& Dhankar, R. S. (2017). Financial instability, integration and volatility of emerging South Asian stock markets. South Asian Journal of Business Studies, 6(2), 177190. https://doi.org/10.1108/SAJBS-07-2016-0059

Mollah, S., \& Mobarek, A. (2009).Market volatility across countries - evidence from international markets.Studies in Economics and Finance, 26(4), 257-274. https://doi.org/10.1108/10867370910995717

Raharjo, S. (2010). Pengaruh inflasi, nilai kurs rupiah, dan tingkat suku bunga terhadap harga saham di bursa efek indonesia. Jurnal PROBANK STIE AUB Surakarta. Retrieved from ejournal.stie-aub.ac.id

Scott, W. R. (2015). Financial Accounting (Sevent). Toronto, Canada: Pearson. 
Thobarry, A. A. (2009). Analisis Pengaruh Nilai Tukar, Suku Bunga, Laju Inflasi Dan Pertumbuhan GDP Terhadap Indeks Harga Saham Sektor Properti (Kajian Empiris Pada Bursa Efek Indonesia Periode Pengamatan Tahun 2000-2008 ). Thesis Magister Manajemen UNDIP. Retrieved from http://eprints.undip.ac.id/19029/1/ACHMAD ATH THOBARRY.pdf

Widodo.(2017). Analisis Pengaruh Indeks Harga Saham Gabungan Regional Asia Terhadap Indeks Harga Saham Gabungan Indonesia.Jurnal Ekonomi Dan Bisnis, 1(2), 148-164.

Zhu, B. (2012). The Effects of Macroeconomic Factors on Stock Return of Energy Sector in Shanghai Stock Market. International Research Journal of Scientific and Reserch Publication, 2(11), 1-4. Retrieved from http://www.ijsrp.org/research-paper-1112/ijsrpp1150.pdf 